\title{
TURKEY AND EUROPE AT A CROSS-ROAD: DRIFTING APART OR APPROACHING EACH OTHER
}

\author{
ANDREA K. RIEMER
}

\section{ABSTRACT}

At the beginning of the $21^{\text {st }}$ century, the EU has reached a difficult position due to a change in the international environtment, an internal renewal and reshaping process. On the other hand, after years of lasting struggle, Turkey was proposed a conditional date to start negotiations at the Copenhagen Summit.

This article analyzes Turkey's road to Europe. It covers a historical review of mixed years lasting relations and follows up the question of selfperception of Turkey and its possible place within the Eurpean Concert. It also covers an assessment of the latest Regular Report of the EU, combines the results of the Copenhagen Summit and possible consequences for the Euro-Turkish relations and beyond.

\section{KEYWORDS}

EU, Turkish-EU relations, EU enlargement, historical aspects of Turkish European relations, Turkish foreign policy 
Turkey has been one of the most ambiguous states, which to become member of the 'House of Europe'. Some call Turkey a 'pivotal state'. ${ }^{1}$ Others name Turkey the 'sick man of Europe'. ${ }^{2}$ Regardless to which group one belongs in Europe - Turkey has become one of the main issues, which has caused a number of frictions and even rifts with the EU in the past fifteen years.

At the beginning of the $21^{\text {st }}$ century, the European Union has reached a difficult position. A fundamentally changed environment and an internal renewal and reshaping process have forced the European Union to face one of its greatest challenges in its existence. The latest enlargement round, which is considered as a historical event in European history, brought some bitter taste for Turkey. After a years lasting struggle for candidacy, Turkey was proposed a conditional date to start negotiations in December 2002 at the Copenhagen Summit. The Treaties of Athens (dated April 2003) and the failure of the summit in Brussels (December 2003) have made the materialization of Turkey's ambitions to join EU as a full member far more difficult. Fights for budgets, vice versa misperceptions and heterogeneous national interests within the Union have prevailed over strategic considerations. But strategy was never an attractive issue for the 'old continent'. Whether Europe will benefit from this 'nonstrategy' remains to be seen. In the light of war against Iraq future perspectives seem dim - for Europe as a global player and for Turkey with regard to EU-membership.

The article will analyze Turkey's road to Europe. It will cover a historical review of mixed years lasting relations and will follow up the questions on the self-perception of Turkey and its possible place within the European Concert. Finally, it will cover an analysis and assessment of the latest Regular Report of the European Union, combined the results of the Copenhagen Summit and possible consequences for the Euro-Turkish relations and beyond.

\footnotetext{
${ }^{1}$ R. S. Chase, E. Hill and P. Kennedy, 'Pivotal States and U.S. Strategy', Foreign Affairs, Vol 75, No. 1, January/February 1996, pp. 33-51. F. S. Larrabee and I. O. Lesser, Turkish Foreign Policy in an Age of Uncertainty, Rand Publication, Santa Monica, CA, 2003, pp. 2-3.

${ }^{2}$ The notion was coined by Czar Nicholas I.
} 


\section{The Road to Europe}

\section{A Historical Overview of the Relations and a First Assessment $^{3}$}

Both histories, the Ottoman and the Turkish history, have been characterized by a number of duplications. ${ }^{4}$ Both histories are examples of multifold disintegrations, of efforts to approach Europe and to play an important role within this construction.

Euro-Ottoman relationships were always rather ambiguous. On one hand and for a long period the Ottoman Empire served as the 'other' for the European powers. This was particularly the case in the $18^{\text {th }}$ and $19^{\text {th }}$ century. On the other hand, the Ottoman Empire contributed considerably to the development and shaping of Europe as such. It may be assumed that both, Europe and the Ottoman Empire have been interlocked on different levels and in different qualities for centuries. Being interlocked is one thing, but being a full-member in Europe is a rather different case. This nexus is also valid for a EUmembership of Turkey.

Legends and myths envelop the early history of the rise of the Ottoman Empire. The construction of the Ottoman Empire took a considerable time and went on rather slowly. The entry of the Turks into Europe was not a cloud-bursting event but a process of gradual infiltration. It went in parallel with the decline and fall of the Byzantine Empire. Historians usually set the Empire's emergence and rise from 1299 to 1453 . It was the period of the constant decline and finally, the collapse of the Byzantine Empire. After the successful bridging of the continent, the Ottomans started a well-planned occupation of, Thrace, Bulgaria, Macedonia, Greece, Serbia, Hungary etc. This occupation laid the basis for the century-lasting influence in

\footnotetext{
${ }^{3}$ For basics see A. Kadioglu, 'The Paradox of Turkish Nationalism and the Construction of Official Identity', in Sylvia Kedourie (ed.), Turkey. Identity, Democracy, Politics, London, Portland: Frank Cass 1998), pp.177-193. D. Kushner, The Rise of Turkish Nationalism, London, Totowa 1977. Andrea K. Riemer, Die Türkei und die Europäische Union: Eine endlose Geschichte ohne Happyend?', in Aus Politik und Zeitgeschichte, 3.3.2003.

${ }^{4}$ See e. g. A. K. Riemer, 'The Arrival of the European International Society in the Ottoman Empire', www.ukc.ac.uk/politics/englishschool/.
} 
the Black Sea and the wider Balkans. Murat I created a wide zone of Pax Ottomanica. He sow the seeds for a multiracial, multireligious, multilingual society.

In 1453, the Ottomans, finally, were successful. On May $29^{\text {th }}$ 1453 the Byzantine capital was taken by them. The conquest led to the unification of the Anatolian and the European parts of their domains. ${ }^{5}$ This event marks the starting point of the peak of the Ottoman Empire. The siege of Vienna (1683) is considered as the starting point of the Empire's end. This 230 -years period was a period of rapid expansion. The Ottomans pushed further into the Balkans (a process that lasted from the $14^{\text {th }}$ to the $17^{\text {th }}$ century) and to the Arab world. Additionally, they spread their influence over North Africa to the eastern border of Morocco. The Black Sea became an Ottoman lake and the eastern Mediterranean fell under Ottoman rule.

During the reign of Suleyman the Magnificent (1520 - 1566) the Ottoman Empire had its largest extension. Suleyman made use of the western disunity, its incoherence and its proneness for the quick economic profit. His final years of reign were already characterized by numerous internal and external changes, which had a strong impact on the further development of the Empire and the following crisis. The reasons for the outbreak of this crisis were as follows: there was no progress in the already highly developed fields of politics and culture. A comprehensive deadlock characterized the Empire, although it presented at that time a comprehensive threat to the still very heterogeneous European entities. In the $16^{\text {th }}$ and $17^{\text {th }}$ century, religious wars in the West led to a temporary paralysis and, finally, to fundamentally new structures. After the destruction of the old system of principalities and statelets, a new category, the sovereign state, emerged. In the wake of this renewal enormous intellectual energy was set free. Science and culture rose and had a strong impact on further societal and political developments. The rise of the 'enlightened citizen' and of the 'enlightened absolute monarch' led to a significant change in the political landscape. With the exemption of the 'patchwork of the German Empire', old kingdoms were transformed to centralist organized states. Feudalism slowly

${ }^{5}$ See V. D. Volkan and N. Itzkowitz, Turks \& Greeks: Neighbours in Conflict, Huntingdon: The Eothen Press, 1994, p. 33. 
faded away. The Age of Reason dominated thinking and led to a comprehensive societal progress.

The Ottoman Empire did not experience this deep-going and fundamental change. It displayed a very strong structural and intellectual inertia. This does not mean still-stand, but it hardly received impact from external developments. The Ottoman Empire was more and more shelved. At the end of the $17^{\text {th }}$ century the tables turned again - not much in favor of the Empire: Russia became a more and more important player in the power game. In parallel, the Empire steadily lost its position in the concert of the players. It was not the formidable enemy, which threatened western Christendom anymore. ${ }^{6}$ It was Europe that posed a threat to the existence of the Empire. During the period, the so-called 'Eastern Question' was born.

The process of a loss of power by the Empire and the reshuffling of influence within the international system continued all through the $18^{\text {th }}$ century. The Empire faced a grave financial crisis and was involved in a number of very costly wars. In the course of $18^{\text {th }}$ century, the Ottoman Empire came more and more in the 'sandwich' between the Habsburg Empire and Russia and their power-games. Both powers were landlocked and tried to secure their areas by setting up so-called glacis. The permanent expansion of the Habsburg Empire, Russia and some less successful efforts of the Empire led to an enormous pressure on one area: The Balkans. At the end of the $18^{\text {th }}$ century, the Empire was about to collapse and Russia emerged as the big Black Sea power. The Empire became a punching ball of European interests, internal struggles, the incapability to deal with the emerging intellectual, technical, economic and societal changes. The newly emerging phenomenon of nationalism was incommensurable with the Islamic founded perception of millet. The new national ideas that came out among the Christian-orthodox peoples in the course of the $19^{\text {th }}$ century were perceived as betrayal to the anyway already groggy Empire. The new ideas were seen as a result of external intervention. The only solution was a brutal suppression. All ideas of the French Revolution were considered as a danger, which threatened the Ottoman Empire. Particularly the idea

${ }^{6}$ See G. Lenczowski, The Middle East in World Affairs, $4^{\text {th }}$ ed., Ithaca, London: Cornell University Press 1985, p. 31. 
of secularization was seen as the key threat. It ran completely opposite the fundamental pillars of Islam and was more or less unacceptable and incommensurable (interestingly, the founder of Turkey, Atatürk, recognized secularization as one of the most important pillars of a modern and working state). Although the Empire stood in sharp opposition to nationally motivated struggles, it slowly took over numerous Western elements. On the external level, the Empire faced considerable turmoil in this period. Various independence wars in the first half of the $19^{\text {th }}$ century supported the plans and aims of the Western powers. The Empire was perceived as an essential market for the emerging western economies. At the same time, the Empire was one of the most important exporters of raw materials for the Western powers. The $19^{\text {th }}$ century become the era of systemic economic exploitation of the Ottoman Empire by Europe. At the end of the century, the Empire was reduced to the level of a developing country.

Politically, the Eastern Question was in the center of attention. Russia played a more and more crucial role in the solution of the question. Russia and Britain had different interpretations on how to solve the question. From the Russian point of view the solution included a division of the Ottoman Empire. Britain saw the situation differently. The differences ended up in the war over Crimea (18541865). The Treaty of Paris (1856) sealed the Russian defeat and, at the same time, forced the sultan to accept equality within the European system. Despite the success in the Crimean war, domestic troubles still prevailed in the Ottoman Empire. The Empire was unable to deal with the rising nationalism in the Balkans. Suppression and cruelties led to broad indignation in Europe. The Treaty of Berlin (1878) presented a hallmark in Russian-Ottoman relationships. The Treaty is regarded as an expression of the ambiguous attitude of the then European powers. They had to square the circle of keeping Russia down (Russian ambitions were cut down to a minimum), preserving the integrity of the Empire and, finally, they had to take care of their own positions. The agreement is an expression of how torn the situation in the then Europe was. Until 1914, the situation remained very unstable. The Ottoman Empire had lost all its political reputation and weight. In the course of World War I, the Empire acted together with the loosing powers, the Habsburg Empire and Germany. The end of World War I marked the official end of the Empire. The Turks (the successor of the Ottoman Empire) always considered the 
Treaty of Sèvres (1920) as a dictated peace. It confirmed the international defeat and the end of the Empire. On April $11^{\text {th }}, 1920$ the then sultan dissolved the parliament. Twelve days later the Grand National Assembly of Turkey convened in its opening session in Ankara. $^{7}$

From 1919 to 1922 the newly emerging state was confronted with resistance from outside (Asia Minor adventure by Greece) and inside (a restoration of the Ottoman court, the ancien régime was intended). For the first time, a new idea gained ground. A territorial nation-state based on the Turkish nation within Turkish borders slowly emerged. The driving force behind was Mustafa Kemal, called Ataturk. His target was not a restoration of the sultan's throne, not a revival of Muslim-Turkish influence, but he wanted to create Turkey.

The creation of Turkey is inseparably linked with the Treaty of Lausanne (1923). It substituted the very unfavorable Sèvres Treaty and is considered as the legal basis for the foundation of modern Turkey. From 1923 onwards Ataturk established Turkey as a regional power. He revolutionized the societal system and wiped all Ottoman elements out. Ataturk's key target was a radical and comprehensive Europeanization of Turkey. He based his ideology (i. e. Kemalism or Ataturkism) on six pillars or (alti ok):

1. Laicism (laiklik): Ataturk separated state and religion; religion became a private matter.

2. Republicanism (cumhuriyetcilik): Turkey became a republic according to western examples.

3. Populism (halkcilik): Refers to a class-less society and a policy which takes the people into account.

4. Nationalism (milliyetcilik): There is only one inseparable Turkish nation (the only separation refers to muslims and non-muslims, Section III, Art. 38 of the Lausanne Treaty).

5. Etatism (devletcilik): The state controls economy, without possessing sole property.

\footnotetext{
${ }^{7}$ See B. Lewis, The Emergence of Modern Turkey, $2^{\text {nd }}$ ed. (Oxford University Press: London, Oxford, New York 1968), p. 364.
} 
6. Reformism (inkilapcilik): Progress has to be achieved on a permanent basis; this is to be understood as a key critique of the Ottoman inertia.

Ataturk saw the particular position of Islam as an all societal areas covering religion as the key danger. He did not forbid religion but put it under state's control. Islam was not a state religion because it was modern civilization which was the pace maker for societal development. The separation of state and religion was seen as the key basis for a modern Turkey.

Between 1923 and 1945 Turkey performed a policy of neutrality and non-engagement. This was seen as the only way to consolidate the newly emerged state. Nevertheless, the heritage of the Ottoman Empire was still alive.

、 After World War II, Turkey did not have many choices within the bipolar system. Turkey was locked in a cage and kept in an ideological or systemic struggle. Due to its geopolitical position it was imprisoned between East and West. Its own weakness forced Turkey to ask for Western support to prevent Soviet aggression on Turkish territory (e.g. Truman Doctrine).

Moreover, the protection of the strategically and economically relevant Turkish Straits became an issue again. The Black Sea which was regarded as the 'soft underbelly' of Russia became a strategic area for the Western Allies. Control over the Black Sea meant control of the Red Army in Central and East European areas. The Straits became a bottleneck. Their protection was one of the key issues. The deterrence of Russia was substituted by deterring the Soviet Union. A NATO-membership - the first step into the Western world - seemed to be the best guarantee against the Soviet Union.

The close Western-Turkish relations, which started with the Truman Doctrine ${ }^{8}$ and the Marshall Plan, were completed by Turkey's full NATO membership (1952). Turkey together with Greece was the main protector of the strategically important Southern

\footnotetext{
8'The Truman Doctrine: The unstoppable boulder. US aid to Greece and Turkey after WW II', The Economist, 14.3.1987.
} 
flank of NATO. Due to common borders with the Soviet Union and the geographical proximity to the troubled regions in the Middle East, Turkey found itself in a special situation. What role does Turkey play in these different circumstances? Turkey has been an OECD member since 1948 and a Council of Europe member since 1949. Moreover, she is part of the security conception via NATO, of which it has been a member since 1952. NATO accession was seen as a fulfillment of Atatürk's dream to become part of the Western hemisphere, the Western society of states and in the long-run a 'European power'.

In 1959, Turkey's ambitious endeavors 'to become a Westernized country' reached a certain paramount level. It applied for associate membership of the then European Community (EC). The reasons behind the application were following: Turkey saw in an association with the EC a confirmation of its Western orientation and vocation. On the one hand, the EC offered a tremendous market potential for the Turkish economy, which was then still undergoing a reshaping procedure. On the other hand, the EC provided the necessary pouvoir for direct foreign investments to promote the economic restructuring process. The final and probably most important reason for the application was the fact that Greece applied at almost the same time. Greece was a positive driving force for Turkey. It was a competition fuelled by historical burdens, mutual misperceptions and jealousies. A certain 'winner-looser syndrome' which is still predominant cannot be denied. It is reflected at the biand multilateral level.

Turkey has been affiliated to the EC through the Ankara Agreement since 1963..$^{9}$ After years of ups and downs and difficult domestic periods (two coup états - 1971 and 1980), Turkey reached a more stable phase at the end the 1980s. In the post putsch era, Turgut Ozal was the leading political personality, who stressed the European vocation of Turkey. On April $14^{\text {th }}, 1987$ Turkey submitted its application for full EC membership. It took more than two years for Ankara to receive a negative answer. Unofficial justifications included demographic, economic, structural and social reasons. Officially, internal reshaping activities of the Community were

${ }^{9}$ The Ankara Agreement was signed on September $12^{\text {th }}, 1963$ and came into effect on December $1^{\text {st }}, 1964$. 
named as reasons. In its answer, the Commission worked out three conditions for Turkish re-application: First, political pluralism has to be increased (which was quite normal after a coup d'état) and Turkey's human rights record has to be improved considerably. Second, the conflict with Greece has to be settled and, third, the Cyprus question has to be solved.

The conditions reflected the reluctance of the Commission to accept Turkey. The time framework had a very broad and longranging dimension, which diluted many of Turkey's ambitions and efforts. The EC did not want to bind itself more than was necessary. An integration of Turkey was seen as a very challenging task with a very unclear road to go and an even more unclear target to reach. The Commission decided to assess Turkey's status from time to time. Reluctance in the answer reflected EC-policy towards Turkey for years to come.

Since 1989 the EU-Turkish relationships have been influenced very much by global changes. Since the dissolution of the Soviet Union a new Europe had been constructed. The end of the post Cold War era and the emergence of a, first, multi-polar system of powers, and, later on, uni-polar system with additional power layers, led to a search for new policies in the community of states. This searching process has been strongly influenced by the highly uncertain global environment. During the Cold War Turkey's role was clear. Within a very short period of time, the basis of Turkey's incorporation into the Western system vanished - there was no need for a buffer anymore. At the same time of the shoving and shaping of the global system, the question of Turkey's European vocation gained ground again. ${ }^{10}$

The broad reshaping of identity and the search process had a strong impact on the EU-Turkish relations. Due to a number of insecurities in the societal environment and some unsolved issues between Turkey and EU-members the 1990s have been characterized by increased tensions and difficulties in the EU-Turkish relationship.

${ }^{10}$ M. Müftüler-Bac, 'Turkey's predicament in the Post-Cold War Era' Futures, Vol. 28, No. 3, pp. 255-256.

A. Mango, Turkey, The Challenge of a New Role, Washington Papers No 163, Washington, DC, 1994, p.110. 
There were the following key obstacles: On the international level, the dispute between Greece and Turkey endangered security in an already troubled area. Greek-Turkish tensions (particularly over the Aegean) turned out to be a main obstacle. The second obstacle has been the pending Cyprus issue. The Turkish position on the separated island, which had been on the diplomatic tables for years, turned into an official blocking factor. Since then the EU has started a 'linkage policy'. The situation became even more complicated when the Republic of Cyprus submitted its application for full membership and the EU gave its approval. The EU hoped with the approval and the start of negotiations (after the end of the Intergovernmental Conference in 1996) to give a boost to solving the pending questions. On the contrary, the EU did not have anything to contribute to a reasonable and sustainable solution. Within a short time, the EU had imported a number of conflicts between a member-state (Greece) and one of its most difficult non-member partners. The complexity of situation turned out as the big stumble block for a further rapprochement between Turkey and the EU.

On the domestic level, the unsolved Kurdish question, the strong influence of the Turkish army on domestic questions, the lack of democracy and Turkey's poor human rights record have been the main obstacles. Even these problems and the negative opinion of the Commission on the application for membership did not completely close the door to Turkey. The Commission stated that co-operation with Turkey should be resumed because the country shows a general openness towards Europe. For this reason, it has been in the interest of the Commission to support the country's efforts to complete the process of political and economic modernization.

Although there have been internal EU problems and open issues between Turkey and Greece, the EU went into a customs union agreement with Turkey. The agreement became effective in 1996. ${ }^{11}$ So far, it brought more a 'one-way-development', favoring the EU and keeping a pro-European mood in Turkey quite suppressed.

\footnotetext{
${ }^{11}$ Commission of the European Communities, Proposal for a Council Regulation Regarding the Implementation of a special Financial Cooperation Measure for Turkey, Brussels, July $26^{\text {th }}, 1995$.
} 
Several times, an opting-out from the agreement was debated by Turkish politicians, but was never seriously pushed forward.

The Luxembourg summit of December 1997 has been regarded as a negative hallmark in EU-Turkish relationships. Instead of offering perspective full membership, the Council suggested drawing up 'A European Strategy for Turkey'. In fact, the Luxembourg summit resulted in big disappointment for Turkey. The proposed 'European Conference' as an interim step and 'waiting room' was seen as a 'political excuse'. Luxembourg led to a massive deadlock in the EU-Turkish relationship. The Luxembourg decision not only led to massive tensions in the Euro-Turkish relationship, but also considerably influenced the Euro-US relationship. It became almost a 'classical example' of different perceptions of Turkey. One of the strongest supporters of Turkey, the United States, could not understand the reasons why the EU had rebuffed Turkey. The United States would have liked to see Turkey on the membership list because. The U.S.-perspective sometime connected EU and NATOdevelopments, particularly in the phase of NATO-enlargement. ${ }^{12}$ Washington blamed the EU for a lack in strategic considerations. The United States believed the EU seemed not to appreciate the extraordinarily important position of Turkey in a shaky but very important geopolitical region, namely Central Asia and the Caucasus. The United States obviously had a far clearer picture of the role and importance of Turkey for the Western alliance than most of the European governments did.

Parallel to the Luxembourg decision, the EU announced the start of negotiations for accession with Cyprus on March $31^{\text {st }}, 1998$. A few months later, some of the members assessed the way the decision making procedure had become public as unfortunate. Luxembourg led to a thorough discussion among the European partners and within Turkey. The 'European vocation of Turkey' became an issue in the discussion.

1999 was a crucial year in Euro-Turkish relations. Since summer 1999 with its gradual improvement of Greco-Turkish relationship it became clear that the Helsinki Summit in December

12'Turkey and the EU: Not so fast', The Economist, 20.12.1997. 
will be of highest importance. The new government was very clear in its program and positioned herself as a very self-conscious partner: "Turkey's full membership in the European Union is its right emanating from history, geography and international treaties. We shall endeavor to realize Turkey's aim of full membership in the European Union with equal rights and status as other members. Turkey will assume its rightful place in the integration process in Europe and while doing this, it will go on protecting its national rights and interests meticulously. In this regard, we shall carefully monitor and exploit all opportunities and developments which may accelerate our relations with the European Union. Turkey will adopt a determined approach aimed at enjoying full and equal footing in political and economic European and Transatlantic institutions and formations as well as those related to security and defense. We shall be engaged in effective initiatives to eliminate the flaws inherent in the implementations of the Customs Union. ${ }^{13}$ ",

The overall situation was promoted by changes in the majority in the European Parliament, by changes in the EU-Commission and by the improvement of Greek-Turkish relationships. It was not fully clear until the Helsinki Summit whether Turkey would be granted candidate status. Finally, the EU-Council decided to give a candidate status to Turkey, but without specifying any time perspective as to when concrete negotiations can be started. Furthermore, no preconditions were named, only recommendations. The active support of Athens of the Helsinki-decision made the candidacy status possible. Helsinki led to a boost in Euro-Turkish relationships. Within Turkey a very vivid discussion on societal issues has been started in the course of the year 2000. This is assessed as an important pre-condition for the often required societal changes in Turkey.

The Accession Partnership Document (ADP) released in November 2000 again led to a backlash. The inclusion of the Cyprusquestion and of the Kurdish question among the short-term political criteria brought an outcry of the Turkish public and led to farreaching re-considerations of Euro-Turkish relationships. Even

\footnotetext{
${ }^{13}$ Programme of the $57^{\text {th }}$ Government presented to the Turkish Grand National Assembly by Prime Minister Bülent Ecevit, $4^{\text {th }}$ June 1999, p. 22.
} 
though the ADP received an amendment in favor of Turkey the situation remained tensed. It was Turkey's turn to set up a National Program for the Adoption of the Acquis (NPAA). The Program was presented with some months delay in March 2001. ${ }^{14}$ It includes a considerable number of intentions and actions.

The recent economic crises brought a 'shift away mood'. Economic questions became existential questions for Turkey (which in fact reflected reality) in this very particular period of the first half of 2001. The EU-question was kept on low key, but, of course, never fully vanished from the political stage. It was mainly played on the stage of ESDI. Progress towards accession continues along the path set by the National Program. The most pressing aim here is the opening of accession negotiations, which depends on the fulfillment of the Copenhagen political criteria. In 2001, Turkey took a number of important steps towards this end. These efforts were acknowledged by the EU at the Laeken European Council of December 14-15, 2001, where for the first time, the possibility of opening accession negotiations with Turkey was explicitly mentioned at the highest level.

Another important decision taken at Laeken is that Turkey was invited to take part in the Convention on the future of Europe on an equal basis with the other candidates. This has been considered as a progressive step, which sends a clear message to the Turkish public opinion that determined efforts to take place within the folds of the Union, has the support of the European partners. In accordance with the Laeken European Council Conclusions, Turkey has been participating actively in the Convention's work with 2 parliamentarians and one government representative.

At the end of the Sevilla European Council of June 21-22, 2002 the Chairman's Conclusions to the effect that depending on the pace of reforms in Turkey, new decisions regarding the next stage of Turkey's membership can be taken at the Copenhagen Summit, is a promising sign.

\footnotetext{
${ }^{14}$ See http//:www.mfa.gov.tr/grupa/ad/adc/Euintroduction.htm. http//:www.mfa.gov.tr/grupa/ad/adc/latest.htm (April decision from the Accession Council).
} 


\section{What is Europe All About? ${ }^{15}$}

One of the key considerations regarding a Turkish fullmembership in the EU refers to the definition of 'Europe'. We assume that there is no single valid definition, but a number of plausible answers. This reflects one of the key problems in relation to Turkey. Is Europe a cultural space, a geographical area and/or historical space? Does 'Europe' refer to arts or philosophy? Or does Europe also refer to unity in diversity? Which role does the time calculus play in these considerations?

If those questions will be answered satisfactorily, one will have a clearer picture regarding Turkey's full-membership in the EU. One approach to gain a better overview is the 'international system/international society approach', mainly promoted by the English School of IR.

The origins of the concept of international society date back to Machiavelli, Hobbes, Grotius and Kant. ${ }^{16}$ The key questions all of them tried to answer are: "What might bring states to co-operate in international life? On what might order and co-operation be based? 17 " Hobbes's and Machiavelli's approach referred to power politics

${ }^{15}$ For further details see:

A. K. Riemer: Semiperiphery States during the post-cold war Era: Theory meets Practise (Frankfurt: Peter Lang, 2002), part. pp. 31-59. A. K. Riemer, 'Die Türkei und die Europäische Union: Eine endlose Geschichte ohne Happyend?', Aus Politik und Zeitgeschichte, B-10-11/2003 dated 3.3.2003. A. K. Riemer, 'The Arrival of the European International Society in the Ottoman Empire, www.ukc.ac.uk/politics/englishschool/. A. K. Riemer/F. W. Korkisch: USA-Türkei-Europa: Ein geopolitisches Spannungsdreieck/US-Turkey-Europe: A geopolitical triangle of tension ( Frankfurt: Peter Lang, 2003).

${ }^{16}$ See e. g. B. Buzan, 'The English School: an underexploited resource in IR', in Review of International Studies (2001), 27, pp. 471-488, part. pp. 474476. A thorough overview of the English School approach to 'international society' is provided by T. Dunne, Inventing International Society: A History of the English School, London: MacMillan, 1998.

${ }^{17}$ A. Hurrell, 'Society and Anarchy in the 1990s', in B. A. Roberson (ed.), International Society and the Development of International Relations Theory, London, Washington: Pinter, 1998, p. 18. 
among states as driving co-operation momentum. Grotius pointed to the institutionalization of shared interest and identity among states. Based on this common ground the creation of norms, institutions and rules represents the key for co-operation. Finally, Kant took a rather comprehensive or world society approach ("universalist cosmopolitan approach').

In this article, the approach from Hedley Bull will be taken as basis. Bull's approach is strongly influenced by Grotius. He refers in his concept of international society to a society of sovereign states. ${ }^{18}$ According to Bull, "A society of states (or international society) exists when a group of states, conscious of certain common interests and common values, form a society in the sense that they conceive themselves to be bound by a common set of rules in their relations with one another, and share in the working of common institutions.... At the same time they co-operate in the working of institutions such as the forms of procedures of international law, the machinery of diplomacy and general international organisation, and the customs and conventions of war. ${ }^{19 "}$ "As opposed to the notion of "international system" which refers in Bull's understanding to power politics among states. ${ }^{20}$ "The concept of 'international society' is seen as a collection of states bound together by common rules (the driver is more the anarchy-element, i. e. states have to work together, for reason they establish certain rules and common practices) and underpinned by the common culture (the driver as a common cultural basis as a basis for co-operation) ${ }^{21}$ Order in the international society is usually based on the existence of common interests and values that refer to primary targets. Rules (i. e. international law, moral rules, custom, established practice; also verbal and non-verbal rules; communicated and noncommunicated rules; formal and informal agreements) determine the pattern of behavior and institutions (since Bull assumes the principle

${ }^{18} \mathrm{He}$ also uses the terms 'state' and 'nation' synonymous.

${ }^{19} \mathrm{H}$. Bull, The Anarchical Society. A Study of Order in World Politics, $2^{\text {nd }}$ ed., MacMillan: London 1995, p. 13. Italics by the author.

${ }^{20}$ See B. Buzan, 'The English School: an underexploited resource in IR', Review of International Studies (2001), 27, pp. 474-475.

${ }^{21}$ See A. K. Riemer and Y. A. Stivachtis (eds.): Understanding EU's Mediterranean Enlargement: The English School and the Expansion of Regional International Societies, (Frankfurt/M.: Peter Lang, 2002). 
of anarchy, i. e. the absence of a central and supreme government, it is the states themselves that are the principal institutions of the society of states) support effectiveness of those rules. ${ }^{22}$ In one of his following works Bull and Adam Watson elaborated and re-defined the notion of international society as "a group of states which not merely form a system, in the sense that the behaviour of each is a necessary factor in the calculations of the others, but also have established by dialogue and consent common rules and institutions for the conduct of their relations, and recognise their common interest in maintaining these arrangement. ${ }^{23}$ " The concept of "international society" is seen as a collection of states bound together by common rules (the driver is more the anarchy-element, i. e. states have to work together, for reason they establish certain rules and common practices) and underpinned by the common culture (the driver as a common cultural basis as a fundament for co-operation). ${ }^{24}$ This is a remarkable extension of the concept. The pure order-aspect (anarchy) is supplemented by design-aspect. There were periods when one aspect/perspective was more dominant than the other one. At the end, it is both aspects that shove and shape international society.

How can these theoretical considerations be applied to the EU? One way of application are the Copenhagen-Criteria. They comprise a stable democracy, respecting human rights, the rule of law, and the protection of minorities; to have a functioning market economy; and to adopt the common rules, standards and policies that make up the body of EU law. Finally, the EU must be in a position to absorb new members. In the meantime, those criteria have become part of the EUTreaty (Art. 6, para. 1) and part of the EU-Charta (Nice, December 2000).

From this point of view, the perception of Europe raises another question, namely: Who are 'we' and who are 'the others'? It

${ }^{22}$ See H. Bull, The Anarchical Society. A Study of Order in World Politics, $2^{\text {nd }}$ ed. (MacMillan: London 1995), p. 51. Also p. 64 and p. 68.

${ }^{23} \mathrm{H}$. Bull and A. Watson, The Expansion of International Society (Oxford: Clarendon Press, 1994), p. 1.

${ }^{24}$ See A. K. Riemer and Y. A. Stivachtis (eds.): Understanding EU's Mediterranean Enlargement: The English School and the Expansion of Regional International Societies, (Frankfurt/M.: Peter Lang, 2002). 
is a question about inclusion and exclusion; it refers to drawing borders. The spiritual concept of Europe is also connected to fears (e. g. the idea of an 'Islamic conquest'; the danger of a 'third Turkish siege' etc.). Playing the 'Islamic card' is a rather superficial argument, which cannot be found in any official EU-document. Nevertheless, this 'card' has been used by individuals in the discussion every now and then. And those individuals were rather successful with their oversimplified and emotionalized arguments. They provoked defense reactions, xenophobic effects and fears of a Muslim population dominance. Those arguments served as an obvious agenda of hidden national interests of political and economic origins. They are based on a deeply rooted psychological complex, which has been existing for centuries. The 'Islamism argument' is a polemic sophism, which is countered by facts: Some 15 Million Muslims currently live within the EU. Additionally, EU subsidies and supports the Balkans (with a large proportion of Muslim population) heavily to guide the states into the EU (e. g. via the Stability Pact). This seems contradictory to the 'Islamism argument', which has been played as an official back-off card against Turkey by some EUmembers.

The notion of 'international system' is often read as opposing to Bull's understanding of society. In his understanding it refers to power politics among states. ${ }^{25}$ "A system of states (or international system) is formed when two or more states have sufficient contact between them, and have sufficient impact on one another's decision, to cause them to behave - at least in some measure - as parts of a whole. $26 "$

In one of the following works, Bull together with Adam Watson, elaborated about and re-defined the notion of international society. Both referred to it as "a group of states which not merely form a system, in the sense that the behaviour of each is a necessary factor in the calculations of the others, but also have established by dialogue and consent common rules and institutions for the conduct

${ }^{25}$ See B. Buzan, "The English School: an underexploited resource in IR", Review of International Studies (2001), 27, pp. 474-475.

${ }^{26} \mathrm{H}$. Bull, The Anarchical Society. A Study of Order in World Politics, $2^{\text {nd }}$ ed. (MacMillan, London 1995), p. 9. Italics by the author. 
of their relations, and recognise their common interest in maintaining these arrangements. ${ }^{27}$ " The concept of international society is seen as a collection of states bound together by common rules. The driver for these common rules is anarchy, which was considered by Bull as the theoretical starting point for his deliberations. His perception of anarchy refers to the absence of a central and supreme government (authority) to regulate relations between states. The states themselves are the principal institutions of the society of states. ${ }^{28}$ According to this principle, states must work together to survive. They establish certain rules and common practices, underpinned by common culture. Common culture serves as a fundament for co-operation. This was a remarkable extension of the original concept. The pure order-aspect (anarchy) was supplemented by the design-aspect (culture). There were periods when one aspect was more dominant than the other one. Finally, both aspects shaped international society. Society and system became two sides of one and the same coin.

Applying those thoughts to the EU, we may say that the EU consists of a network of sovereign, independent states; those states preserved their individuality because of the society aspect and despite the fact of handing over some sovereignty aspects to Brussels. The concept of sovereignty, which dates back to the Westphalian Peace Accord $(1648)^{29}$ and the Peace Treaty of Utrecht (1713) is still of

${ }^{27} \mathrm{H}$. Bull and A. Watson, The Expansion of International Society (Clarendon Press, Oxford, 1994), p. 1.

${ }^{28}$ See H. Bull, The Anarchical Society. A Study of Order in World Politics, $2^{\text {nd }}$ ed.,(MacMillan, London 1995, p. 51 . Also p. 64 and p. 68.

${ }^{29}$ The agreement is understood as a critical event in the development of the modern sovereign state system characterized by legally independent, territorial, and autonomous political entities. In fact, the Peace of Westphalia is a double agreement, thereby covering the Treaty of Osnabrueck (concluded between the Habsburg monarch who was the Holy Roman Emperor and the Protestant rulers of Sweden) and the Treaty of Muenster (concluded between the Emperor and the Catholic King of France). It ended a decades-lasting struggle between different religions (Catholics and Protestants) and introduced equality between the players/actors by promoting a different organizing concept other than religion. The agreement was based on the Augsburg principle of cuius regio, eius religio, i. e. the prince determines the religion of the subjects, thereby including some religious tolerance and equal treatment of different 
burning topical importance. It protects smaller states from too much dominance of bigger ones. Finally, a systemic definition of Europe has always been connected to power politics and to the preservation of a certain 'systemic balance'. This clearly emerged under Metternich (1814/15) and nothing has changed until today.

The stronger the society idea became, the stronger the systemic thought emerged. We may assume the existence of promoting and preventing forces, which work at the same time. Over the time line, it is both perspectives (changing in terms of velocity and intensity), which create Europe and support the crossing of the narrow geographical borders. This interplay between society and system is reflected in many EU-issues. Even though many do not like to listen to the expression of the 'European Club', we may consider this term as another expression for the 'Concert of Europe'. We must not oversee that the 'Concert' under Metternich was far more harmonious and stringently organized than the multi-voice EU-quire ever has been and ever will be.

If the EU is a system and a society at the same time, one can not be choosy and claim to be part only of one. The resulting complexity and exclusiveness have caused numerous, very wellknown problems for EU in relation to Turkey. For this reason, it has been impossible to achieve clear-cut answers. It is the overall package which makes Europe the Europe we see it - with all its facets, multivoices, rifts and communalities. This overall package draws the line between 'us' and 'them'.

religions. This change had enormous impact in the structure of the 'network of relationships'. The 'Westphalian state' with all its attributes became the leading form of polity in Europe and had a strong shoving and shaping impact on the 'overall/global network of actors'. The Peace of Westphalia was intended to provide a basis that helped to avoid new religiously underpinned wars and, consequently, bolstered regime stability in Europe. Many of the provisions on the Westphalian Agenda were not brand new, but a reaffirmation of already existing rights and duties. What Westphalia definitely did, was a codification of rules which were applied in a less formalized and less equal way before. The Westphalian Treaty has been regarded as more than only a symbolic origin of the European International System. 
The Latest Regular Report of the European Union and Copenhagen and Beyond

The status quo analysis of Euro-Turkish relations is based on Turkey's Annual (2002) Progress Report, released on October 9, 2002, by the European Commission. The Report underlines the progress made by Turkey towards the adoption of EU-acquis but, at the same time much to our disappointment and regret, concludes that Turkey has not completely met the Copenhagen political criteria. According to the 2002 Progress Report, the Commission considered the recent reforms and implementation as still insufficient and expected further reforms to eliminate the last obstacles to meet the Copenhagen Criteria. The report made no reference to the opening of accession negotiations. Instead, the Commission recommended a reinforced pre-accession strategy, an enhanced dialogue, an administrative capacity development and an increased financial cooperation.

The following paragraphs provide a summary of the Reports assessment, following the Copenhagen Criteria.

\section{Political Criteria}

The political criteria refer to democracy, the rule of law, human rights and the protection of minorities. The Turkish Parliament adopted a major constitutional reform in October 2001. It aimed at strengthening guarantees in the field of human rights and fundamental freedoms and limiting capital punishment. A new Civil Code was adopted in November 2001. It provides numerous fundamental changes, such as equality of women and men and special protective provisions for children. Another three major sets of reform packages were adopted in February, March and August 2002. The adoption of these reforms demonstrated that the majority of Turkey's politicians is ready to move towards the values and standards of the European Union. They represent a major shift in Turkish positions. Key issues in the debate were the abolition of the death penalty, Radio/TV broadcasting and education in languages other than Turkish (part. in Kurdish). These reforms were adopted in a difficult and volatile 
political and economic environment. ${ }^{30}$ It is remarkable that those major reforms were based on a broad political consensus and an intensive public debate. Political parties, civil society, business as well as academic circles participated in this vivid discussion and provided very important input. Additionally, the dialog between the Parliament and the President has enhanced and become very vivid. The President frequently used his right to veto and has become an important element in the checks and balances. The judiciary system has faced a number of positive changes. The special position of the state security courts has be reformed and curtailed. The courts in general are still very delayed in dealing with the various cases. Interpretation of laws still differ considerably. Equal treatment, transparency, clarity and legal security are not fully guaranteed. The role of military courts in civil trials does still not comply with EUstandards.

Additionally, the reform packages contain a law on political parties and their dissolution based on court decision. Dissolution reasons have been restricted. It remains to be seen how the new regulation will be applied in practice.

Minority protection has improved only marginally. The Treaty of Lausanne (1923) is still the point of reference for the Turkish government. The Report demands firmly further and substantial improvements to comply with EU-standards.

The National Security Council is still one of the most debated 'institutions'. The Report considers it as a European anachronism. Its range of activities needs to be further curtailed. The Council must have only a consulting function. Currently, it is considered as the 'hidden government'. This is unacceptable according to EUstandards.

Summing up, Turkey has made the greatest progress in the year 2002 - despite very difficult societal, economic and political conditions -all in all a very unfavorable framework for reforms. The

${ }^{30}$ After months of instability and a weeks lasting government crisis, the Turkish Parliament decided in August 2002 to hold early election on November 3, 2002. 
important issue will be to implement the laws and provisions, thereby proving that deeds do follow words. This will be considered as a litmus test whether Turkey is serious about its European ambitions or whether its word is just a hollow phrase.

\section{Economic Criteria}

Turkey's economy has been in problematic conditions since years. Particularly the volatility of key economic data gave room to worry whether Turkey will be in a sustainable position to cope with the economic pressure from the common market. The reasons for the economic troubles are historically conditioned and mainly structurally rooted. The political system has functioned as a hampering overlayer, it wasted the scarce domestic capital and sucked off the foreign investment. Additionally, the political system has been responsible for the hostile climate for any foreign engagement. Finally, Turkey has suffered considerably from too ambitious and partly not well-thought efforts to stabilize its economy.

After years of struggling, Turkey has achieved a basic consensus on which a working market economy should function. This should improve its capacity to cope with competitive pressure and market forces within the Union. The progress is considered as the key condition to move away from 'election economics' and to move towards a coherent and effective economic program (and hopefully to channel incoming investments).

Some of the well-intended efforts to turn the economy around have caused a soaring inflation. They made the systemic weaknesses of the finance sector evident - something Turkish government have been very reluctant to restructure, since politics and finance had a traditionally close relation, which rarely was for the benefit of the citizens and the small companies. Economic growth and population growth show a rather volatile development. It was the unstable economic growth, particularly during the 1990 s, which led to a considerable decline in the per-capita income. Inflation additionally fueled this development. The income-gap between the North/Northeast and the rest of the country has increased. The urbanrural gap shows a similar development. Unemployment rose due to the two grave recessions in 1999 and 2001. Particularly youth 
unemployment in cities has turned out to be a major problem. The exchange rate policy, which was based on the crawling peg in December 1998, was changed in February 2001 to a free floating. This step caused an up-heated inflation, which affected all income brackets. Only in the last year inflation started to decline to a remarkable level of $20 \%$ p.a. (the lowest level in the past 25 years). Finally, it led to a considerable siphoning of purchasing power. Privatization was not successful, despite numerous efforts in the past few years. Legal provisions were not enough to bring ambitious and well-intended programs through. Within Turkey, the necessary capital is lacking. Seen from outside, Turkey is not stable enough to encourage foreign direct investments and to present an attractive investment opportunity. Increasing investment into productive uses and devoting particular attention to education is important to increase the competitiveness and the growth potential of the economy. The inflow of foreign direct investments has to be encouraged by simplifying bureaucratic procedures and by removing remaining barriers.

The economic crisis in Russia (1998) and the earthquakes (1999) undermined many well-intended efforts to smooth out economic deficits. Finally, the lack in backing up fierce economic programs (after a start-up euphoria) has led to further set-backs. Turkey is still far away from fulfilling the Maastricht-Criteria. Currently, Turkey is not in a position to deal with the market forces and a competitive pressure. From the macro-economic point of view, Turkey is unstable. Actors within the economic system cannot decide under accountable conditions.

Despite the critical screening and the clear remarks, the Report names a number of positive and encouraging aspects, such as:

After several attempts to stabilize the economy, the current reform program is slowly producing positive results. Growth has resumed. Fiscal discipline has been improved and the transparency of public sector accounts has increased considerably. Political interference, a main source for Turkey's economic instability, has been reduced and structural weaknesses, such as a fragile and distorted banking sector, have been tackled (though not fully completed). Particularly the role of the central bank, financial market regulations and supervision have been strengthened. Additionally, a 
number of steps to increase the public sector's performance and the transparency of the public budget have been set.

Important steps have been taken to liberalize key markets, such as agriculture, tobacco, electricity, gas and telecommunication. Further reducing chronically high inflation and maintaining fiscal discipline are important pre-conditions to this end. Prudential and accounting standards in the banking sector have to be brought in line with international norms.

The privatization of state banks and enterprises has to be accelerated (still a lot has to be done) and the market deregulation completed. The reform of the social security system is assessed as a very important step.

Summing up, Turkey will have to go through a very long and painful restructuring process until it will be able to meet the EUstandards. This requires domestic stability and accountability. Foreign support will definitely not be enough to iron out the deficits. Turkey has done an encouraging start. Still, a number of steps need to be done.

\section{Ability to Assume the Obligations of Membership ('Acquis Communautaire')}

This section refers to the question of Turkey's ability to assume the obligations of membership. It comprises the legal and institutional framework, known as the acquis, by means of which the Union implements its objectives.

Turkey has made progress in aligning legislation in the areas covered by the Customs Union. Progress has also been achieved in areas such as the banking sector, telecommunications, energy and agriculture. The financial sector has been restructured and administrative capacity in this field has been streamlined. Little progress has been achieved in other areas. Major discrepancies between the acquis and Turkish legislation still remain. Administrative capacity needs to be strengthened. Regarding the internal market, in the area of free movement of goods, the framework law on the free circulation of products adopted in 2001 has entered 
into force. Various pieces of implementing legislation have been adopted throughout a wide range of sectors. Substantial technical barriers to trade remain. Substantial work also remains to be done to establish and improve the functioning of various bodies. No progress can be reported in the field of free movement of persons. In the field of free movement of capital, important restrictions on foreign investment in various sectors have remained. The implementation of legislation in the field of money laundering should be given greater attention. Turkey's alignment concerning financial services is well advanced, and further progress has taken place in 2001, in the framework of the reorganization of the financial sector. In the field of competition policy, the application of anti-trust provisions remains satisfactory. Overall, progress on alignment with the acquis in the field of agriculture is limited.

\section{Criteria not Covered by the Copenhagen-Criteria, but of High Relevance for a Turkish EU-accession}

Apart from above mentioned issues, some other questions are of relevance in the Euro-Turkish relations. They comprise:

The societal development between tradition and modernity: The debate between Kemalists and moderate representatives of modernity has characterized Turkish history from the very first moment of Turkey's existence (the issue dates back to the Ottoman heritage, which is still present in the Turkish society). Tradition is still prevalent in the rural areas. Kemalism could not change that much as it intended and remained stuck among the Ottoman elites. Modernity has been mainly confined to the Turkish élites. Additionally, many aspects, which have grown in Europe, are strange to Turkey and the Turks or even incommensurable with their selfperception. Slowly but steadily, a Turkish middle class has emerged in recent years - particularly in the urbanized areas. Turkey has started to take the road, but still there is a long march ahead. This lagging behind could result into a field of tension, which can be considered as a 'hidden integration potential' - as many EUrepresentatives do so.

The development of the population: Turkey has experienced a fierce population growth in the past 75 years. Currently, Turkey has 
$67.8 \mathrm{~m}$ inhabitants (census 2000). The share of young population has been constantly increasing, whereas the portion of retired people has decreased. The labor market has suffered considerable from this imbalance. Moreover, population growth has been accompanied by a steady urbanization. Currently, $66 \%$ live in urban areas. Domestic migration has turned out as one of the grave problems in Turkey in past twenty years. Rural areas have become unattractive. Urban areas have been overwhelmed by young people, who streamed into the cities and hoped to be able to build-up a new existence. Since cities did not offer appropriate jobs, many young Turks migrated. Migration to the EU would be far easier if Turkey is a full-member. This caused many fears among EU-member states. Cheap Turkish workers could 'flood' the EU-labor market - something no member is interested in, since the internal labor market situation anyway has been very tense. Population development would affect another crucial issue, namely the number of deputies for the European Parliament. As a consequence, a strong Turkish Parliamentarian presence would have strong influence on many decisions within the EU. It has not been said officially yet, but one may assume that none of the current EUmembers will be interested in the dominance by an Islamic country. This attitude stands in contradiction to the argument of 'not playing the Islamic card' (which is the rational way of consideration). The nexus between population growth, Islam and EU-domination has served as an excellent populist argument in many member states. The emotionalized and simplified way of argumentation was very well sold as a joker for some EU-members (or political parties in EUcountries such as the CDU in Germany) to keep Turkey out - not only in public mood and opinion. It seems obvious that the 'populationIslam argument' served as one of the arguments to keep Turkey at arm's length, but no one within the EU dares to spell it out, yet.

The societal gap: Turkey is a country, which displays considerable gaps between the different regions, between rural and urban areas. Cities like Istanbul or Ankara show a remarkable standard of living. Cities located in the Southeast cannot compete with them. Population developments, the tense labor market situation, income gaps, the vanishing of the families as a traditional network etc. forces the state to jump in. In case of a full-membership, EU will have to take over the supportive role to a large extent. This is not in the interest of the large participators in the cohesion funds, such as 
Portugal, Greece or Spain. They will clearly object any further rise in financial support.

Those three additional aspects are of high importance for any assessment of a Turkish EU-accession. They are hardly mentioned in official EU-reports and are very difficult to be assessed. But it is undeniable that they exist and have a strong impact on the overall decision.

\section{The Copenhagen Summit and the Year 2003 - An Outlook}

International reaction to the Copenhagen Summit and the decision of the European Council on Turkey in December 2002 were rather mixed. They spanned from 'EU has been blackmailed by Turkey' to 'there is still hope' and 'fortunately, the decision has been postponed'. Turkish reaction was - after an understandable first disappointment - rational. "The decisions taken at the Copenhagen European Council regarding Turkey fell short of our expectations. Nevertheless, they are perceived as a basis of a new stage in TurkeyEU relations. ${ }^{31}$ "

It seems obvious, that Turkey is on the right path, but it has to deal with a lot of work to be able to comply with EU-standards. The new government showed encouraging signals, despite the fact that the very recent months have been overshadowed by the standoff with Iraq and the following war. Turkey joined the majority of European states, which were against the war. The strong stance of Abdullah Gül and his efforts to prevent the war were perceived very positively among many EU-members. Turkey gained points within EU, but it lost ground vis à vis the United States. The Turkish behavior in the talks before the war, the unlucky decision in the Turkish Parliament on the 'troop issue', the resumption of the talks with the U.S. in summer 2003 and the resumption of the troop issue in October 2003 (with a positive decision of the Parliament, but a rather vague mandate) and the final decision not the dispatch troops to Iraq left Turkey with a mixed impression. This picture will also affect relations with the EU in the long run, a Union which is split, characterized by national

${ }^{31} \mathrm{http}: / /$ www.mfa.gov.tr/grupa/ad/adc/latest.htm, query dated 4.1.2003. 
interests and no strategic vision, a Union which has reached an organizational over-stretch, as proven in the wake of the Brussels summit in December 2003. 2003 was a challenged year for Turkey with very mixed results in every direction. With regard to EU-Turkish relation it was a year to take a deep breath for 2004, the year of decision.

With regard to the EU-position, it seems obvious that the Union has to have a clear stance on a possible Turkish fullmembership by 2004. It will be very difficult for the EU to place any further excuses and weak arguments, if Turkey will come close to fulfillment. EU will not be in a position to apply double-standards anymore - at least if the Union likes to maintain its creditworthiness. Otherwise the project 'Europe' would suffer considerable and sustainable damage - if it will be still alive in the current constellation.

If the EU will not be successful by 2004 to harmonize its different opinions and inner tensions with regard to itself and to Turkey, and Turkey will, at the same time, not comply to the Copenhagen Criteria, there will be the following alternatives:

1. Both give up the idea of a full-membership in favor of a strategic partnership, including the customs union. This option does not exist yet; it would be a 'lex Turkey', which needed to be fabricated. This step would be a deviation from the Ankara Agreement. A materialization of this option would possibly lead to considerable damage of both parties' image.

2. Turkey could lean stronger on the United States. In the light of the Iraq-war, one has to wait and see how the bilateral relations will develop after the war. The current situation is characterized by a slight détente. Much will depend on the war effects on Turkey and a possible Turkish role in the reconstruction of Iraq.

3. Another alternative would be to turn more towards the Islamic world. A number of signals have already pointed to this option, e. g. Turkey's efforts in the pre-war phase to avoid the war. One must not forget that Turkey is in a delicate position. It is a Muslim, but secular state. This has 
brought the country in a unique position among Muslim countries. Nevertheless, the current government seems to be a fertile ground for this alternative.

Particularly in the light of the war against Iraq, the delicate geopolitical position of Turkey and its multifold disintegration clearly emerged. ${ }^{32}$ It is obvious, that none of the big players can and will keep Turkey out of its considerations, be it the United States or the European Union. If Europe wants to gain a strategic stronghold in the region, it has to find a solution for its relationship with Turkey. Additionally, a clarification of the Euro-Turkish relations will contribute to the clarification of the question 'what is Europe all about?'. An answer to this question is vital to the very existence of Europe in general and the EU in particular.

${ }^{32}$ See A. K. Riemer, Das amerikanisch-türkische Verhältnis: Nachhaltig beschädigt oder nach wie vor eine stabile strategische Achse?, Das Parlament, 9. Mai 2003. 


\title{
THE UNITED STATES AND TURKEY'S MEMBERSHIP IN THE EUROPEAN UNION
}

\author{
SABRI SAYARI
}

\begin{abstract}
Washington's support for Ankara on the issue of Turkish membership in the EU became part of the agenda of U.S.-Turkish bilateral relations in the late 1980s. However, it was during the course of the next decade that American officials began to engage in intensive lobbying efforts among key U.S. allies in Europe to promote Turkey's EU aspirations. This article is analyzing the motives behind the US support for Turkey's bid for membership in the EU and the differences in the approaches between the US and the EU on this issue.
\end{abstract}

\section{KEYWORDS}

EU, Turkish-US relations, Turkish-EU relations, Turkish foreign policy, US Foreign Policy, EU-US relations. 